\title{
Two new species of the genus Premicrodispus (Acari: Microdispidae) associated with beetles (Coleoptera: Lucanidae: Tenebrionidae), with a key to Palaearctic species of the genus
}

\author{
Farahnaz Hosseininaveh, Hamidreza Hajiqanbar* and Ali Asghar Talebi \\ Department of Entomology, Faculty of Agriculture, Tarbiat Modares University, Tehran, Iran
}

(Received 19 August 2013; accepted 17 June 2014; first published online 9 October 2014)

\begin{abstract}
Two new species of mites of the genus Premicrodispus Cross, 1965 (Acari: Microdispidae) are described and illustrated from northern Iran: Premicrodispus paramaevi Hosseininaveh and Hajiqanbar sp. nov. recovered from Lucanus ibericus (Col.: Lucanidae) and Premicrodispus spinosus Hosseininaveh and Hajiqanbar sp. nov. from Corticeus unicolor (Col.: Tenebrionidae). It is the first phoretic record of the microdispid mites on beetles of the family Tenebrionidae. A key to Palaearctic species of the genus Premicrodispus is provided.
\end{abstract}

http://zoobank.org/urn:1sid:zoobank.org:pub:49368637-B8D0-4697-918428B33B89962A

Keywords: Heterostigmatina; mite; beetle; phoretic relationship; Iran

\section{Introduction}

Mites of the cohort Heterostigmatina (Acari: Prostigmata) usually have phoretic, parasitoid or parasitic associations with various orders of insects. Within the Heterostigmatina, phoretic relationships have been evolved mostly in the superfamily Pygmephoroidea (Kaliszewski et al. 1995; Khaustov 2008). Based on Khaustov (2008), this superfamily includes four families, one of them the family Microdispidae. The microdispid mites are inhabitants of soil, forest litter and the nests of insects, and many of them use insects for phoretic dispersal (Khaustov 2009). Fungivory appears to be the primitive feeding behaviour of this family (Kaliszewski et al. 1995). The family consists of 17 genera and more than 109 species (Zhang et al. 2011). One of the speciose microdispid genera is the genus Premicrodispus. Khaustov (2006) reviewed the history of the genus. This genus currently includes three subgenera, Premicrodispus sensu stricto with about 27 species (according to Khaustov and Maslov 2013) and two monotypic subgenera Premicrodispulus Khaustov and Chydyrov, 2010 and Premicrodispoides Khaustov and Maslov, 2013. Hitherto, the subgenus Premicrodispus (Premicrodispus) included 20 described species in the Palaearctic region (Khaustov 2006, 2009; Khaustov and Chydyrov 2010). Mites of this family have been found on beetles of the families Carabidae, Scarabaeidae and Lucanidae (Hajiqanbar et al. 2012) but this study reports, for the first time, these mites on beetles of the family Tenebrionidae.

During a preliminary study of the heterostigmatic mites associated with Coleoptera in Iran, we found two new species of the genus Premicrodispus. This paper describes these new species and is the first record of the phoretic association

*Corresponding author. E-mail: hajiqanbar@modares.ac.ir 
between mites of the family Microdispidae and beetles of the family Tenebrionidae. A key to Palaearctic species of the genus Premicrodispus is provided.

\title{
Material and methods
}

Host beetles were captured directly in their habitats from Naharkhoran forest, Golestan province, northern Iran in 2009. Mite specimens were collected from a vial containing host beetles in alcohol, cleared in lactophenol and mounted in Hoyer's medium. The morphology of the mites was studied using a light microscope with phase contrast (Olympus BX51, Tokyo, Japan). The terminology used in the description follows that of Lindquist (1986). All measurements in the descriptions are given in micrometres for the holotype and five paratypes, if available (in parentheses). Details of the geographical position were recorded using a global positioning system (GPS model: eTrex).

The holotypes of the new species are deposited in the Acarological Collection, Department of Entomology, Faculty of Agriculture, Tarbiat Modares University, Tehran, Iran. One paratype of each species is deposited in the Zoological Institute, University of Hamburg, Hamburg, Germany. The insect hosts and the rest of the paratypes are retained with the holotype.

\section{Systematics}

\author{
Family MICRODISPIDAE Cross, 1965 \\ Genus Premicrodispus Cross, 1965 \\ Premicrodispus (Premicrodispus) paramaevi Hosseininaveh and Hajiqanbar sp. nov.
} (Figures 1-5)

\section{Description}

Female. Length of idiosoma 181 (178-184), width 95 (91-97).

Gnathosoma (Figure 3A,B). Gnathosomal capsule about twice as long as its width, dorsally with two pairs of cheliceral setae $c h_{1} 7$ (7-8) and $c h_{2} 9$ (8-10); ventrally with one pair of subcapitular setae su 7 (7-9); palps short, terminated to small tibial claw, and compressed to gnathosomal capsule, with two pairs of setae, $d F e$ 5 (4-5) and $d G e$ 4 (3-4); cheliceral stylets indiscernible; pharyngeal system (Figure 3C) with three pumps, pumps 1 and 3 reduced, pump 2 large and striated.

Idiosomal dorsum (Figure 1). Prodorsal shield (PrS) with elongate stigmata and distinct tracheal system; all dorsal setae smooth and pointed; prodorsal shield with one pair of capitate trichobothria and one pair of setae $s c_{2} 19$ (16-19); all tergites smooth, tergite C with two pairs of setae $c_{1} 22$ (19-22) and $c_{2} 24$ (20-24); tergite D with one pair of setae $d 29$ (25-29) and one pair of rounded cupuli ia; tergite EF with two pairs of setae $e 21(18-21)$ and $f 25$ (22-26), setae $f$ longer than setae $e$; tergite $\mathrm{H}$ with two pairs of setae $h_{1} 21$ (18-21), $h_{2} 20$ (16-20) and one pair of rounded cupuli ih; Distances between dorsal idiosomal setae: $s c_{2}-s c_{2} 22$ (22-23), $c_{1}-c_{1} 31$ (27-31), $c_{2}-c_{2}$ 52 (52-58), $d-d 13$ (13-15), e-e 55 (48-55), e-f 13 (12-14), f-f 23 (23-26), $h_{1}-h_{1} 13$ (13-14), $h_{1}-h_{2} 18$ (13-18), $h_{2}-h_{2} 47$ (40-47). 


\section{$50 \mu \mathrm{m}$}



Figure 1. Premicrodispus paramaevi sp. nov., female. Dorsum of the body. 
$918 F$. Hosseininaveh et al.

\section{$50 \mu \mathrm{m}$}

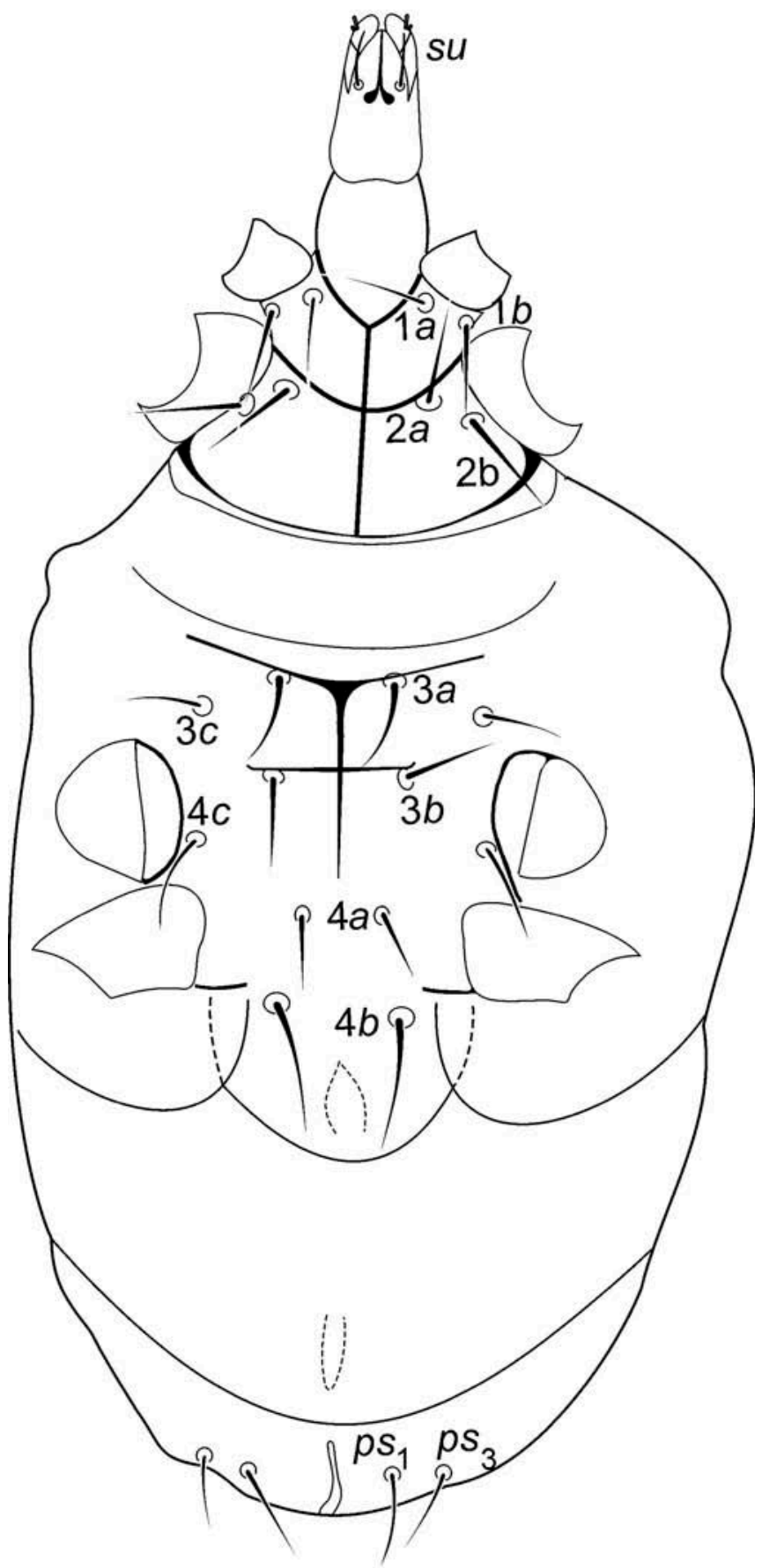

Figure 2. Premicrodispus paramaevi sp. nov., female. Venter of the body. 

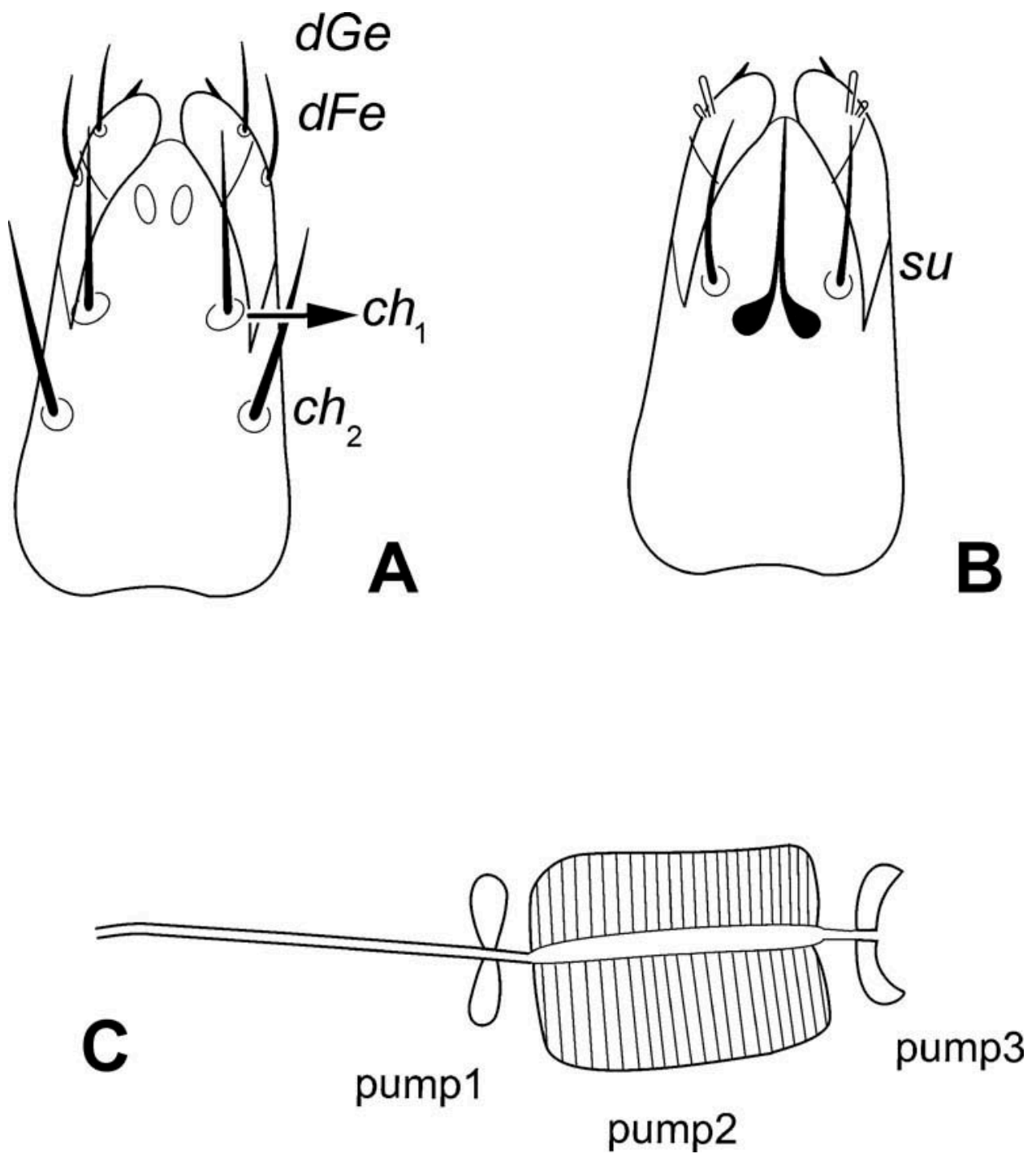

Figure 3. Premicrodispus paramaevi sp. nov., female. (A) Gnathosoma, dorsal view; (B) gnathosoma, ventral view; (C) pharyngeal pumps.

Idiosomal venter (Figure 2). Ventral plates smooth; all ventral setae smooth and pointed; apodemes 1 and 2 reaching to presternal apodeme (appr), sejugal apodeme (apsej) joined with appr, apodemes 3 extending beyond setae $3 a$ and apodemes 4 reaching to setae $3 b$, apodeme 5 short; anterior border of poststernal plate concave and posterior border of poststernal plate tripartite; coxal field I with two pairs of setae $1 a 14$ (13-14) and $1 b 14$ (13-14); coxal field II with two pairs of setae $2 a 19$ (16$19)$ and $2 b 17$ (14-17); coxal field III with three pairs of setae $3 a 14$ (12-14), $3 b 14$ (13-14) and $3 c 13(10-13)$, setae $3 b, 3 a$ and $3 c$ subequal; coxal field IV with three pairs of setae $4 a 11(10-11), 4 b 18$ (16-18) and $4 c 14$ (12-14); pseudoanal segment PS with two pairs of setae $p s_{1} 12(11-12)$ and $p s_{3} 11(10-11)$. 


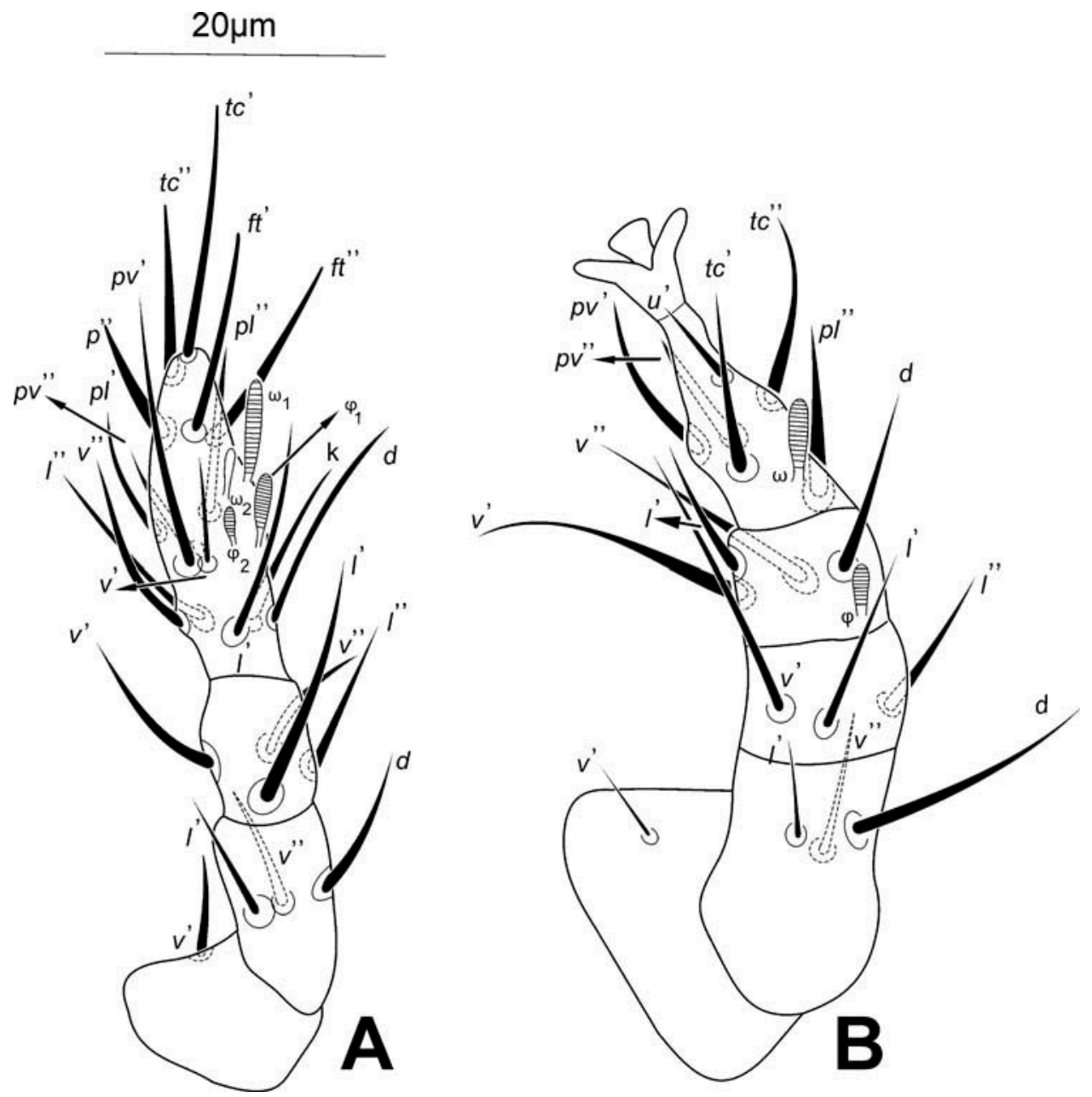

Figure 4. Premicrodispus paramaevi sp. nov., female. (A) Leg I; (B) leg II.

Legs. All legs five-segmented except leg I (four-segmented).

Leg I (Figure 4A). Setal formula: Tr1-Fe3-Ge4-TiTa15(4) (number of solenidia in parentheses). Tibiotarsus with solenidion $\omega_{1} 8$ (7-8), $\omega_{2} 4(4-5), \varphi_{1} 6$ (6-6) and $\varphi_{2} 3$ (3-3), solenidia $\omega_{1}, \varphi_{1}$ and $\varphi_{2}$ finger-shaped and striated, $\omega_{1}$ longer than $\varphi_{1}$ and $\varphi_{2}$, solenidion $\omega_{2}$ uniformly thin; with five eupathidial setae $\left(p^{\prime \prime}, f t^{\prime}, f t^{\prime \prime}, t c^{\prime}, t c^{\prime \prime}\right)$, setae $t c^{\prime}$ longer than $t c^{\prime \prime}$, setae $p v^{\prime}$ longer than $p v^{\prime \prime}$; setae $d$ longer than $k$, setae $v^{\prime \prime}$ longer than $v^{\prime}$, setae $l^{\prime}$ longer than $l^{\prime \prime}$; genu with setae $l^{\prime}$ longer than other setae of the segment, setae $v^{\prime}$ and $v^{\prime \prime}$ subequal; femur with setae $l^{\prime}$ and $v^{\prime \prime}$ subequal and both shorter than $d$; trochanter with seta $v^{\prime}$.

Leg II (Figure 4B). Setal formula: Tr1-Fe3-Ge3-Ti4(1)-Ta6(1). Tarsus with solenidion $\omega 6$ (6-7) finger-shaped, setae $p v^{\prime \prime}, p v^{\prime}$ and $p l^{\prime \prime}$ subequal, setae $u^{\prime}$ shortest on this 

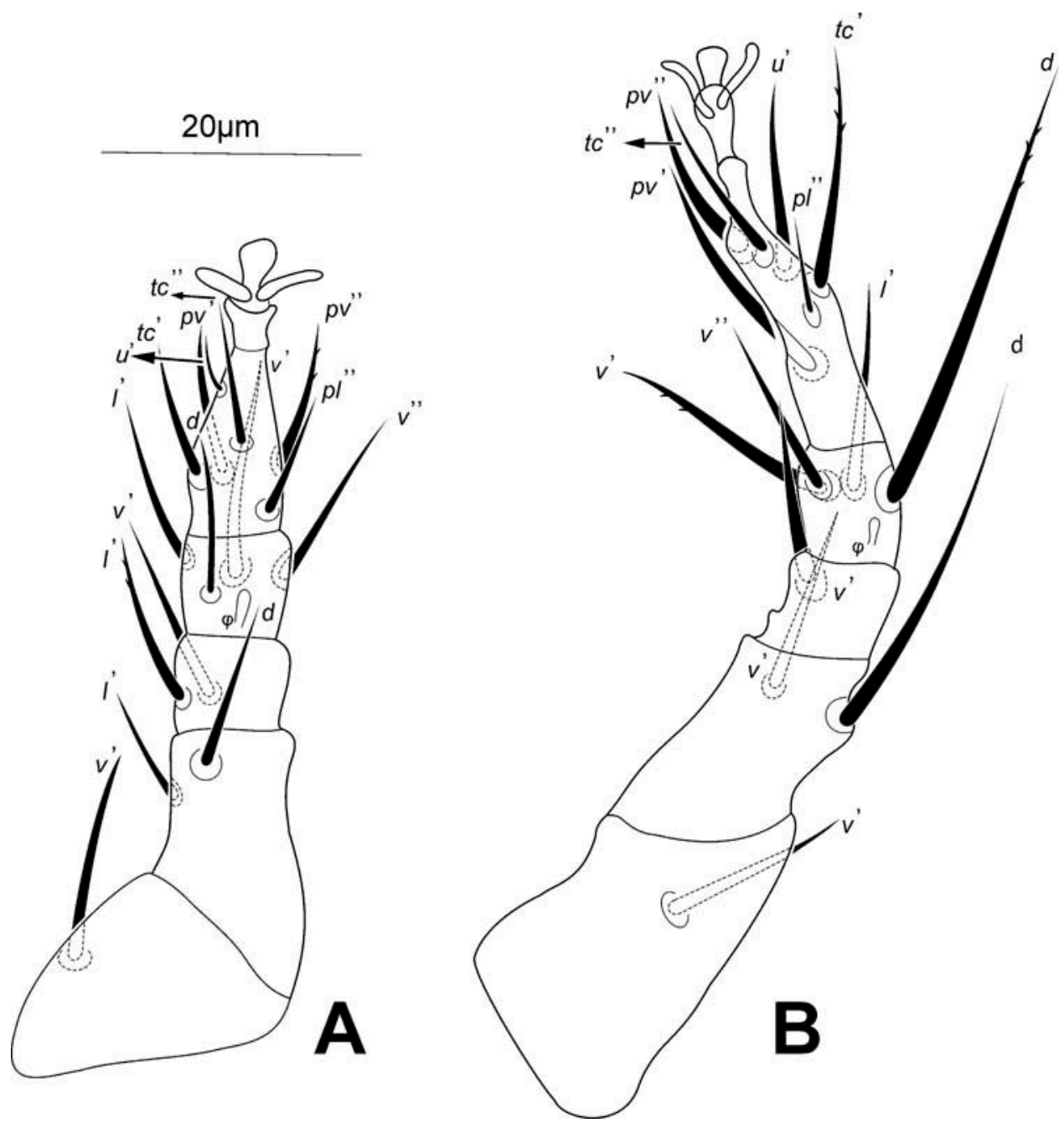

Figure 5. Premicrodispus paramaevi sp. nov., female. (A) Leg III; (B) leg IV.

segment; tibia with a finger-shaped solenidion $\varphi 4(3-4)$, setae $v^{\prime}$ longer than $v^{\prime \prime}$, setae $v^{\prime \prime}$ longer than $d$ and $l^{\prime}$; genu with three setae, $v^{\prime}$ longer than $l^{\prime}$ and setae $l^{\prime}$ longer than $l^{\prime \prime}$; femur with seta $d$ longer than $v^{\prime \prime}$ and setae $v^{\prime \prime}$ longer than $l^{\prime}$; trochanter with seta $v^{\prime}$.

Leg III (Figure 5A). Setal formula: Tr1-Fe2-Ge2-Ti4(1)-Ta6. Tarsus with setae $p l^{\prime \prime}$, $p v^{\prime}, p v^{\prime \prime}, t c^{\prime \prime}$ and $t c^{\prime}$ subequal, setae $p v^{\prime \prime}$ weakly barbed, setae $u^{\prime}$ shortest on this segment; tibia with solenidion $\varphi 2(2-3)$ and setae $d, l^{\prime}$ and $v^{\prime \prime}$ shorter than $v^{\prime}$; genu with seta $l^{\prime}$ weakly barbed and shorter than $v^{\prime}$; femur with setae $d$ longer than $v^{\prime}$; trochanter with seta $v^{\prime}$.

Leg IV (Figure 5B). Setal formula: Tr1-Fe2-Ge1-Ti4(1)-Ta6. Tarsus with seta $t c^{\prime}$ longer than $t c^{\prime \prime}$ and weakly barbed, setae $p v^{\prime}$ longer than $p v^{\prime \prime}$, setae $u^{\prime}$ as long as $p v^{\prime \prime}$, setae $p l^{\prime \prime}$ shortest on the leg; tibia with small solenidion $\varphi 2(1-2)$, setae $v^{\prime \prime}, v^{\prime}$ and $l^{\prime}$ 
subequal and almost two times shorter than $d$, setae $d$ and $v^{\prime}$ weakly barbed; genu with seta $v^{\prime}$ as long as femoral seta $v^{\prime}$; femur with setae $d$ about two times longer than $v^{\prime}$; trochanter with seta $v^{\prime}$.

Male and larva unknown.

\section{Differential diagnosis}

The new species is distinguished from congeners by having two pairs of cheliceral setae, rounded cupuli and reduced pump 3 of pharyngeal system. On the other hand, due to presence of setae $4 a$, absence of setae $p s_{2}$ and subequal setae $p s_{1}$ and $p s_{3}$, the new species is similar to Premicrodispus parasilvestris (Rack, 1974) but differs from it by setae $d$ distinctly longer than distance between their bases (setae $d$ distinctly shorter than distance between their bases in $P$. parasilvestris). The new species is similar to Premicrodispus dzumaevi (Sevastianov and Chydyrov, 1991) because of setae $d$ distinctly longer than distance between their bases but differs from it by subequal setae $p s_{1}$ and $p s_{3}$ (setae $p s_{1}$ distinctly longer than $p s_{3}$ in $P$. dzumaevi). The new species is also similar to Premicrodispus lambi (Krczal, 1964) but differs from it by setae $s c_{2}$ shorter than distance between their bases (setae $s c_{2}$ longer than distance between their bases in $P$. lambi), by setae $d$ longer than distance between their bases (setae $d$ shorter than distance between their bases in $P$. lambi), by setae $f$ subequal to distance between their bases (setae $f$ as half as distance between their bases in $P$. lambi), by setae $h_{1}$ longer than distance between their bases (setae $h_{1}$ shorter than distance between their bases in P. lambi) and by shorter setae in coxal fields I-IV (longer setae in coxal fields I-IV in P. lambi).

\section{Type material}

Three females found in a vial containing the beetle Lucanus ibericus (Col.: Lucanidae) in $75 \%$ ethanol. The host beetle was collected in Naharkhoran forest, Golestan province, northern Iran, $36.46^{\circ} \mathrm{N}, 54.27^{\circ} \mathrm{E}$, altitude $450 \mathrm{~m}$., coll. V. Rahiminejad, 27 July 2010.

\section{Etymology}

The name of the new species 'Paramaevi' is derived from combination of two species names parasilvestris and dzumaevi, two species that are most similar to the new species.

\section{Premicrodispus spinosus Hosseininaveh \& Hajiqanbar sp. nov.}

(Figures 6-10)

\section{Description}

Female. Length of idiosoma 152 (152-156), width 80 (74-88).

Gnathosoma (Figure 8A,B). Gnathosomal capsule about twice as long as its width, dorsally with one pair of cheliceral setae ch 3 (3-3); ventrally with one pair of 


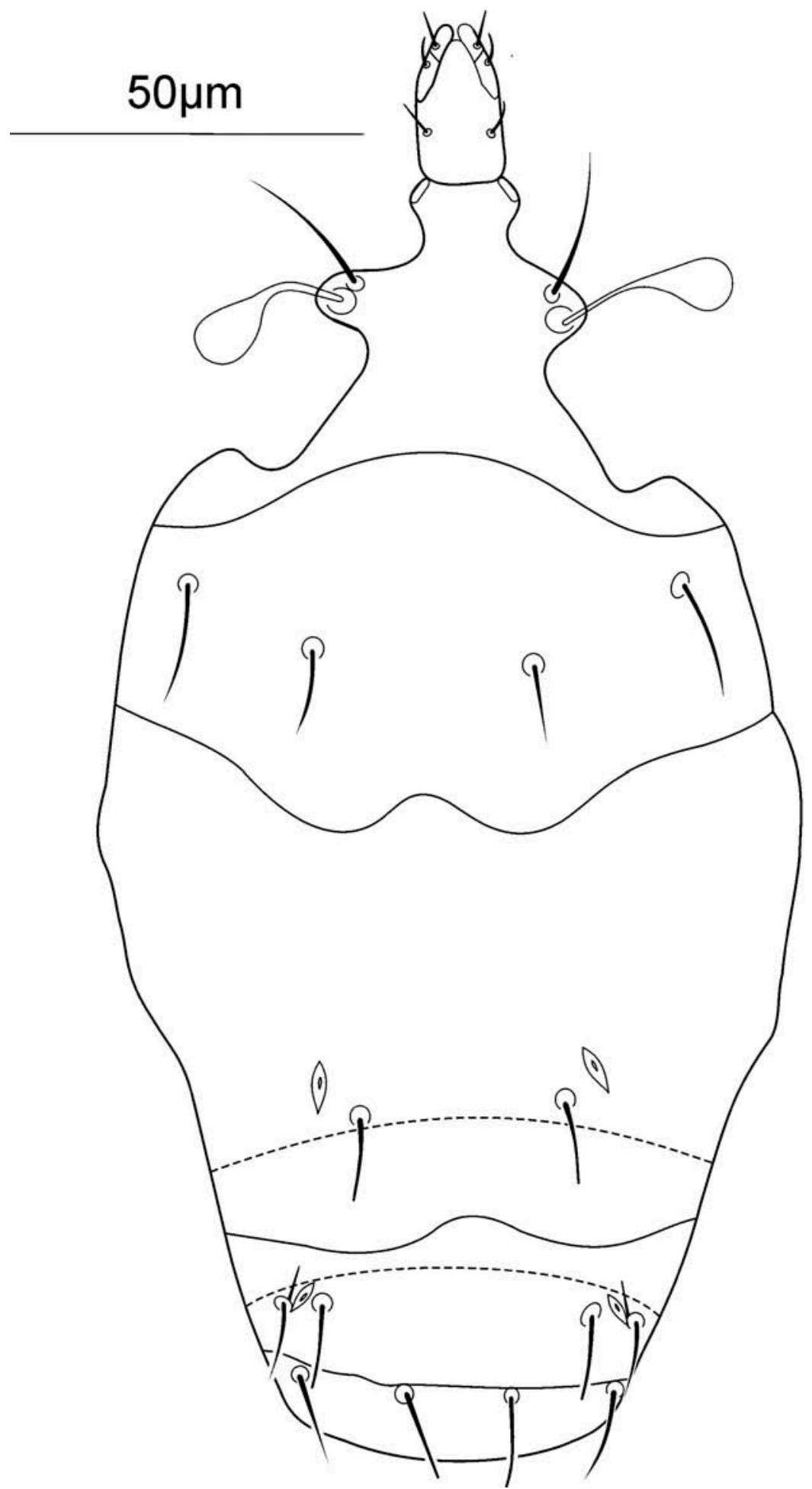

Figure 6. Premicrodispus spinosus sp. nov., female. Dorsum of the body. 
$924 F$. Hosseininaveh et al.

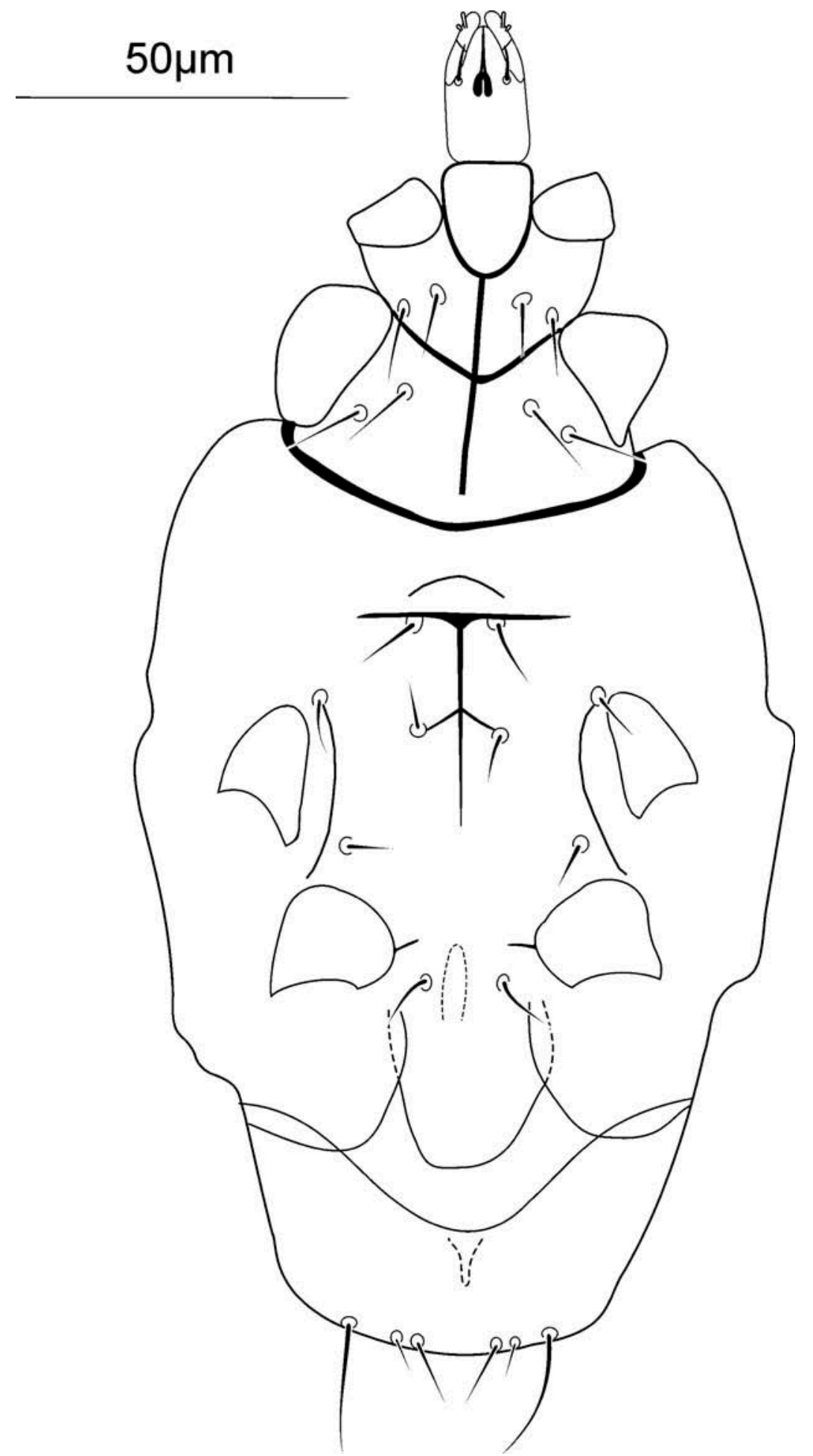

Figure 7. Premicrodispus spinosus sp. nov., female. Venter of the body. 


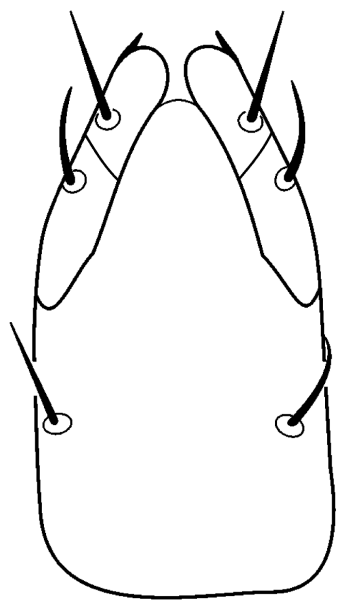

\section{$10 \mu \mathrm{m}$}
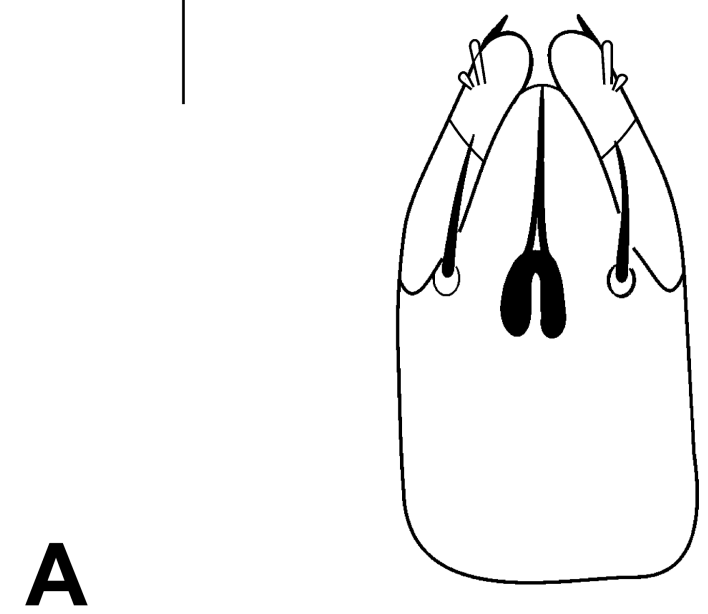

B



Figure 8. Premicrodispus spinosus sp. nov., female. (A) Gnathosoma, dorsal view; (B) gnathosoma, ventral view; (C) pharyngeal pumps.

subcapitular seta su 5 (4-5); palps short, terminated to small tibial claw, and compressed to gnathosomal capsule, with two pairs of setae, $d F e ~ 3$ (3-4) and $d G e \quad 4$ (3-4), cheliceral stylets indiscernible; pharyngeal system (Figure 8C) with three pumps, pump 1 reduced, pump 2 the largest and striated, pump 3 small and rounded.

Idiosomal dorsum (Figure 6). Stigmata oval-shaped and situated in anterior part of prodorsal shield; all dorsal setae smooth and pointed except setae $d, f$ and $h_{1}$, which are blunt-ended; prodorsal shield with one pair of capitate trichobothria 

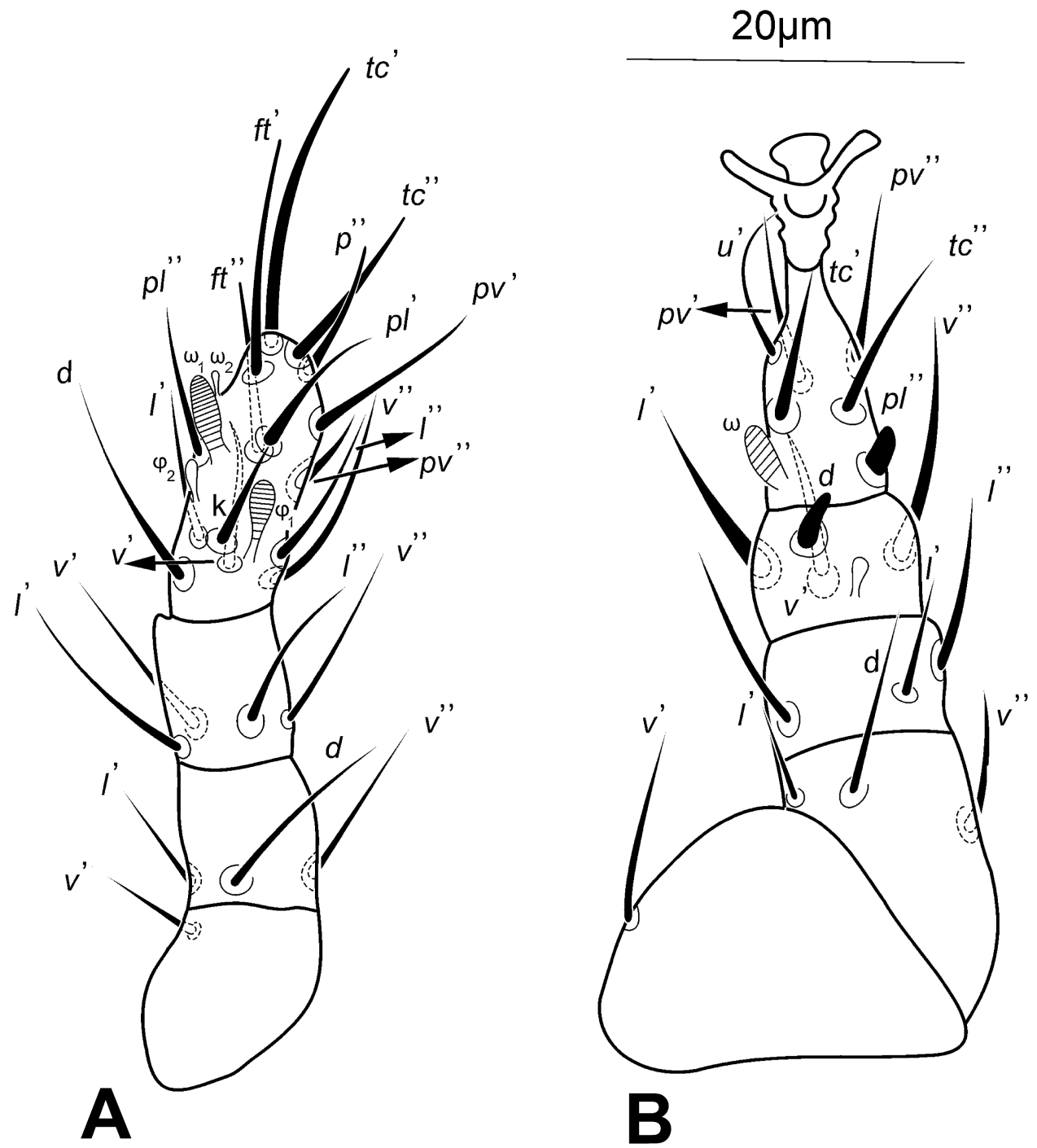

Figure 9. Premicrodispus spinosus sp. nov., female. (A) Leg I; (B) leg II.

and one pair of setae $s c_{2} 19$ (18-19); all tergites smooth, tergite $\mathrm{C}$ with two pairs of setae $c_{1} 11(11-13)$ and $c_{2} 15(13-15)$, setae $c_{2}$ longer than $c_{1}$, posterior border of tergite $\mathrm{C}$ with distinct median depression; tergite $\mathrm{D}$ with seta $d 9$ (9-10) and one pair of rhombic cupuli $i a$, posterior border of tergite $\mathrm{D}$ with distinct median depression; tergite EF with two pairs of setae e 10 (10-11) related to one thin apodeme and $f 10(10-11)$; tergite $\mathrm{H}$ with two pairs of setae $h_{1} 10(10-11), h_{2}$ 11(11-12) and one pair of rhombic cupuli ih. Distances between dorsal idiosomal setae: $s c_{2}-s c_{2} 26$ (25-26), $c_{1}-c_{1} 25$ (25-26), $c_{2}-c_{2} 57$ (50-60), $c_{1}-c_{2} 17$ (17-20), $d-d$ 24 (24-26), e-e 41 (41-44), e-f 5 (5-6), f-f 31 (31-35), $h_{1}-h_{1} 12$ (11-13), $h_{1}-h_{2} 12$ $(11-12), h_{2}-h_{2} 36$ (36-39). 

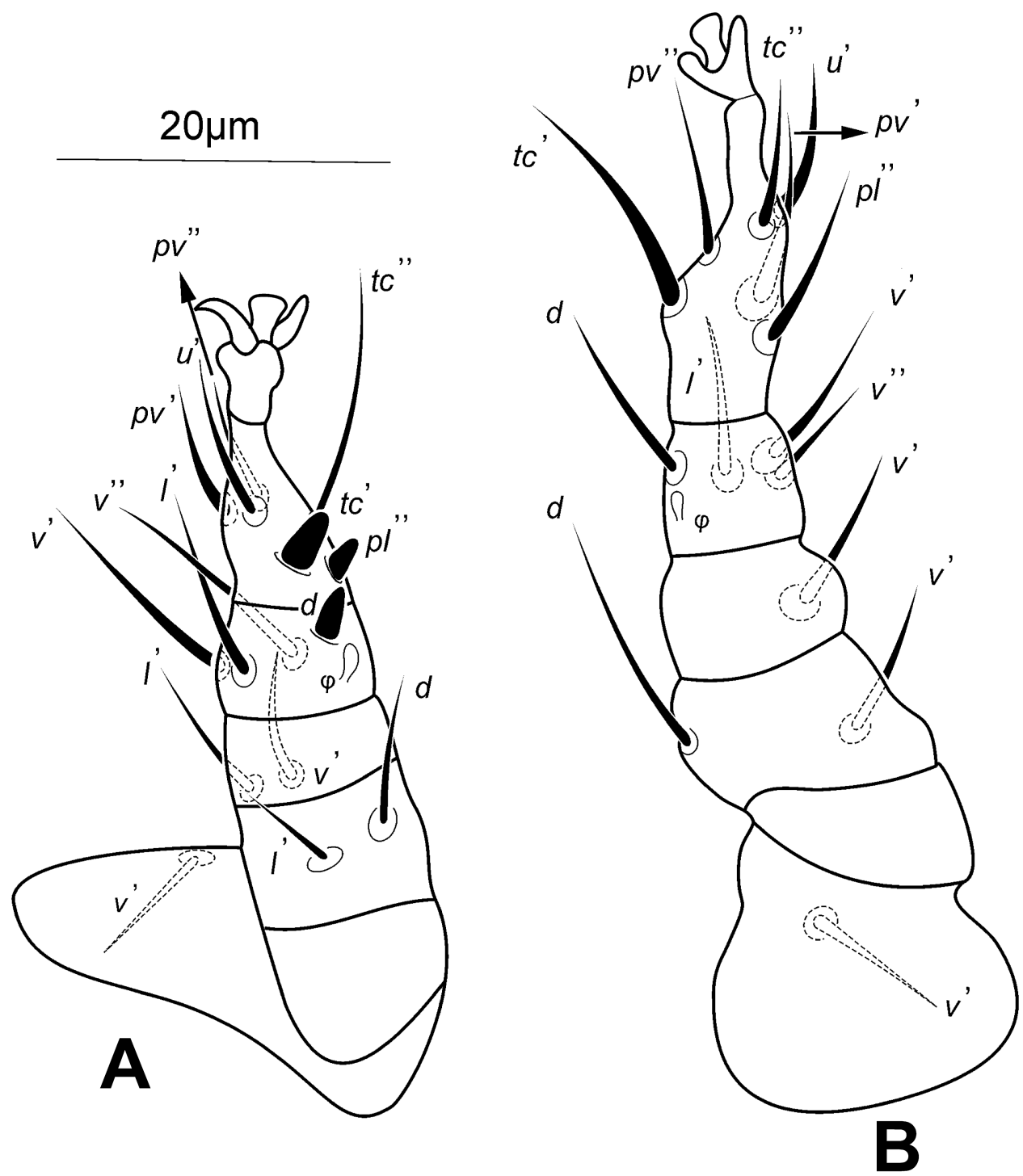

Figure 10. Premicrodispus spinosus sp. nov., female. (A) Leg III; (B) leg IV.

Idiosomal venter (Figure 7). Ventral plates smooth; all ventral setae smooth and pointed; apodemes 1 and 2 reaching to appr, appr not reaching to apsej, apodemes 3 extending beyond bases of setae $3 a$, apodemes 4 short and not reaching to bases of setae $3 b$, apodemes 5 short; anterior border of poststernal plate convex and posterior border of poststernal plate tripartite; coxal field I with two pairs of setae $1 a 10(9-10)$ and $1 b 10$ (10-11); coxal field II with two pairs of setae $2 a 11(11-12)$ and $2 b 14$ (1315), $2 b$ longer than $2 a$; coxal field III with three pairs of setae $3 a 10$ (9-10), $3 b 7$ (7-8) and $3 c 7$ (7-10), $3 b$ and $3 c$ subequal and shorter than $3 a$; coxal field IV with two pair of setae $4 b 8$ (8-9) and $4 c 7$ (7-8); pseudanal segment PS with three pairs of setae $p s_{1}$ 11 (10-11), $p s_{2} 6$ (5-6) and $p s_{3} 18$ (16-18), $p s_{3}$ distinctly longer than $p s_{1}$ and $p s_{2}$. 
Legs. Leg chaetotaxy as in previous species.

Leg I (Figure 9A). Tibiotarsus with solenidia $\omega_{1} 5(4-5), \omega_{2} 1$ (1-2), $\varphi_{1} 2$ (1-2), and $\varphi_{2}$ 4 (3-4), all finger shaped, $\omega_{1}$ and $\varphi_{1}$ striated, with five eupathidial setae ( $p^{\prime \prime}, f t^{\prime}, f t^{\prime \prime}, t c^{\prime}$, $t c^{\prime \prime}$ ), setae $t c^{\prime}$ longest on leg I, setae $p l^{\prime \prime}$ and $p l^{\prime}$ subequal, setae $p v^{\prime}$ longer than $p v^{\prime \prime}$, setae $v^{\prime \prime}$ longer than $v^{\prime}$, setae $l^{\prime}$ and $l^{\prime \prime}$ subequal; genu with setae $l^{\prime \prime}, l^{\prime}, v^{\prime}$ and $v^{\prime \prime}$, all subequal; femur with setae $d$ and $v^{\prime \prime}$ subequal and both longer than $l^{\prime}$; trochanter with seta $v^{\prime}$.

Leg II (Figure 9B). Tarsus with solenidion $\omega 3$ (2-3) finger shaped, $p l^{\prime \prime}$ modified and spine-like, the rest of setae of the segment subequal; tibia with a small finger-shaped solenidion $\varphi 2$ (1-2), setae $l^{\prime}$ modified and spine-like, setae $d$ longer than $v^{\prime}$ and $v^{\prime \prime}$; genu with setae, $l^{\prime \prime}$ and $v^{\prime}$ subequal and longer than $l^{\prime}$; femur with setae $d$ longer than $l^{\prime}$ and $v^{\prime \prime}$; trochanter with seta $v^{\prime}$.

Leg III (Figure 10A). Tarsus with modified and spine-like setae $p l^{\prime \prime}$ and $t c^{\prime}$, setae $t c^{\prime \prime}$ longest setae on the leg, setae $p v^{\prime \prime}$ and $p v^{\prime}$ subequal and shorter than $u^{\prime}$; tibia with a small solenidion $\varphi 2(1-2)$ and setae $d$ modified and spine-like, seta $v^{\prime \prime}$ and $v^{\prime}$ subequal and longer than $l^{\prime}$; genu with setae $l^{\prime}$ and $v^{\prime}$ subequal; femur divided into basifemur and telofemur, setae $d$ and $l^{\prime}$ inserted on telofemur, setae $d$ longer than $l^{\prime}$; trochanter with seta $v^{\prime}$.

Leg IV (Figure 10B). Tarsus with subequal setae $p l^{\prime \prime}, p v^{\prime}$ and $p v^{\prime \prime}$, setae $u^{\prime}$ and $t c^{\prime \prime}$ subequal, seta $t c^{\prime}$ longest on the segment; tibia with small solenidion $\varphi 1(1-1)$, seta $d$ and $v^{\prime}$ subequal and longer than $l^{\prime}$ and $v^{\prime \prime}$; genu with seta $v^{\prime}$ as long as femoral seta $v^{\prime}$; femur divided into basifemur and telofemur, setae $d$ and $v^{\prime}$ inserted on telofemur, seta $d$ longer than $v^{\prime}$; trochanter with seta $v^{\prime}$.

Male and larva unknown.

\section{Differential diagnosis}

The new species is readily distinguished from other species of the genus by some spine-like setae on tarsi and tibiae II and III. Other species of the genus Premicrodispus have unmodified setae on these segments. Disregarding this character, the new species is similar to Premicrodispus tenuisetus Khaustov, 2006 but differs from it by setae $d$ blunt and not extending to posterior border of tergite D (seta $d$ pointed and extending to posterior border of tergite $\mathrm{D}$ in $P$. tenuisetus) and setae $f$ and $h_{1}$ blunt (setae $f$ and $h_{1}$ pointed in P. tenuisetus).

\section{Type material}

Five females found in a vial containing the beetle Corticeus unicolor (Col: Tenebrionidae) in $75 \%$ ethanol. The host beetle was collected from oak trees in Naharkhoran forest, Golestan province, northern Iran, $36.46^{\circ} \mathrm{N}, 54.27^{\circ} \mathrm{E}$, and altitude 450 m., coll. V. Rahiminejad, 30 July 2010. 


\section{Etymology}

The species epithet refers to some spine-like setae on tarsi and tibiae II and III.

\section{Key to subgenera and Palaearctic species of the genus Premicrodispus (females) (modified from Khaustov 2006)}

1. Genu I with four setae, genu II with three setae

- Genu I with three setae, genu II with one seta subgenus Premicrodispulus, P. reductus Khaustov and Chydyrov, 2010

2. Coxal fields I with two pairs of setae, pharyngeal pump 2 much longer than pharyngeal pump 3 subgenus Premicrodispus 3

- Coxal fields I with one pair of setae, pharyngeal pump 2 distinctly shorter than pharyngeal pump 3 subgenus Premicrodispoides, P. punctatus Khaustov and Maslov, 2013

3. Setae $4 a$ present 4

- Setae $4 a$ absent 8

4. Setae $p s_{2}$ present P. stenops (Mahunka, 1969)

- Setae $p s_{2}$ absent

5. Bases of setae $f$ associated with well-developed apodeme

P. lineatus (Mahunka, 1986)

- Apodemes associated with bases of setae $f$ absent

6. Setae $p s_{1}$ distinctly longer than $p s_{3}$

P. dzumaevi (Sevastianov and Chydyrov, 1991)

- Setae $p s_{1}$ and $p s_{3}$ subequal in length

7. Setae $d$ distinctly longer than distance between their bases, bases of setae $e$ without apodemes $P$. paramaevi sp. nov.

- Setae $d$ distinctly shorter than distance between their bases, bases of setae $e$ with apodemes P. parasilvestris (Rack, 1974)

8. Setae $p s_{2}$ present

- Setae $p s_{2}$ absent

9. Setae $h_{2}$ distinctly shorter than $h_{1}$

P. akermanae (Sevastianov and Zahida Al Douri, 1988)

- Setae $h_{2}$ subequal or longer than $h_{1}$

10. Setae $h_{1}$ much shorter than $h_{2}$, pseudanal setae distinctly shorter than setae of posterior sternal plate

P. subvarsoviensis (Mahunka and Zyromska-Rudska, 1975)

- Setae $h_{1}$ and $h_{2}$ subequal, pseudanal setae and setae of posterior sternal plate subequal

11. Setae $h_{1}, d$ and $f$ blunt-ended, tarsi and tibiae II and III with spine-like setae...... $P$. spinosus sp. nov.

- Setae $h_{1}, d$ and $f$ pointed, tarsus and tibia III with setiform setae 


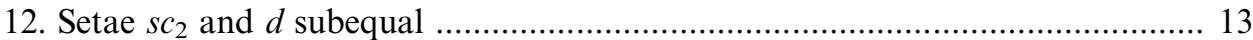

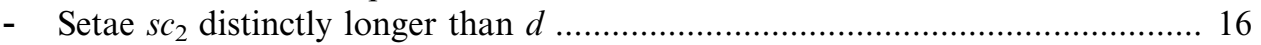

13. Tergites $\mathrm{C}$ and $\mathrm{D}$ with distinct emarginations in central part

P. incisus Khaustov and Chydyrov, 2010

- Tergites C and D without distinct emarginations in central part .................. 14

14. Setae $p s_{1}$ and $p s_{3}$ subequal in length ....................................................... 15

- Setae $p s_{3}$ distinctly longer than $p s_{1}$ P. heterocaudatus Khaustov and Chydyrov, 2010

15. Setae $f$ short and distinctly not reaching to posterior margin of the body P. acutisetus Khaustov, 2009

- Setae $f$ long and protruding the posterior margin of the body P. longisetosus (Mahunka, 1970)

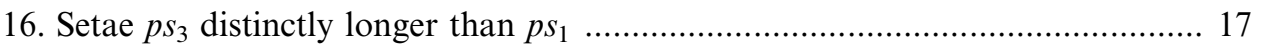

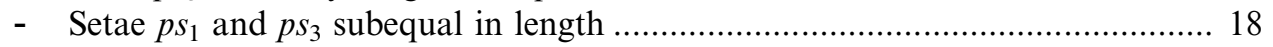

17. Tarsus III with well-developed solenidion

P. paradoxus Khaustov and Chydyrov, 2010

- Tarsus III without well-developed solenidion ..... P. longicaudus Khaustov, 2006

18. Anterior margin of posterior sternal plate distinctly convex .......................... 19

- Anterior margin of posterior sternal plate straight P. kaliszewskii Khaustov, 2006

19. Bases of setae $e$ associated with well-developed apodemes ........................... 20

- Apodemes associated with bases of setae $e$ absent or vestigial ....................... 21

20. Setae $s c_{2}$ and $c_{1}$ subequal, setae $c_{2}$ and $c_{1}$ situated almost at the same level $P$. rackae Khaustov, 2006

- Setae $s c_{2}$ distinctly longer than $c_{1}$, setae $c_{2}$ situated distinctly anterior to $c_{1} \ldots \ldots$. P. brevisetus Khaustov, 2006

21. Setae $e$ shorter than setae $f$ 22

- Setae $e$ longer than setae $f$ P. krczali Khaustov, 2006

22. Setae $c_{1}$ and $e$ blunt ended ......... P. obtusisetosus Khaustov and Chydyrov, 2010

- Setae $c_{1}$ and $e$ pointed 23

23. All dorsal setae long and barbed

P. karadagensis Khaustov, 2009

- Dorsal setae short and usually smooth P. montanus Khaustov, 2006

\section{Acknowledgements}

We express our appreciation to Vahid Rahiminejad for collecting the material. We also thank Dr A. Anichtchenko for help to identify lucanid host beetle.

\section{References}

Hajiqanbar H, Rahiminejad V, Fathipour Y. 2012. New insect host records for mites of the family Microdispidae (Acari: Heterostigmatina), with description of a new species of the genus Paramicrodispus. Entomol Sci. 15: 309-313. doi:10.1111/j.1479-8298.2012.00515.x 
Kaliszewski M, Athias-Binche F, Lindquist EE. 1995. Parasitism and parasitoidism in Tarsonemina (Acari: Heterostigmata) and evolutionary considerations. Adv Parasit. 35:335-367. doi:10.1016/S0065-308X(08)60074-3

Khaustov AA. 2006. A review of the genera Premicrodispus Cross, 1965 and Dolichodispus gen. nov. (Acari: Microdispidae) of Crimea. Acarina. 14:155-174.

Khaustov AA. 2008. Mites of the family Scutacaridae of Eastern Palaearctic. Kiev: Akademperiodyka; $291 \mathrm{pp}$.

Khaustov AA. 2009. A new genus and three new species of the family Microdispidae (Acari: Heterostigmata) from Crimea. Acarina. 17:65-73.

Khaustov AA, Chydyrov P. 2010. Five new species and a new subgenus of Premicrodispus mites (Acari: Heterostigmata, Microdispidae) from Turkmenistan. Zoologichesky Zhurnal. 5:1-13. Russian.

Khaustov AA, Maslov SI. 2013. A new subgenus and species of the genus Premicrodispus (Acari: Heterostigmata: Microdispidae) from Crimea. Acarina. 21:91-95.

Krczal H. 1964. Pygmephorus lambi, eine neue Pyemotide aus Champignonkulturen. Zool Anz. 172:318-322.

Lindquist EE. 1986. The world genera of Tarsonemidae (Acari: Heterostigmata): a morphological, phylogenetic and systematic revision with a reclassification of family-group taxa in the Heterostigmata. Mem Entomol Soc Canada. 118:1-517. doi:10.4039/entm118136fv

Mahunka S. 1969. 176. Pyemolidae and Scutacaridae IV. Ergebnisse der zoologischen Forschungen von Dr. Z. Kaszab in der Mongolei (Acari). Reichenbachia. 12:83-112.

Mahunka S. 1970. Considerations on the systematics of the Tarsonemina and the description of new European taxa (Acari: Trombidiformes). Acta Zool Hung. 16:137-174.

Mahunka S, editor. 1986. Tarsonemids of the Kiskunság National park (Acari). In: The Fauna of the Kiskunság National park. Budapest: Akademiai Kiado; p. 435-455.

Mahunka S, Zyromska-Rudska H. 1975. Two new tarsonemid mites from Poland (Acari: Tarsonemida). Folia Ent Hung. 282:295-299.

Rack G. 1974. Neue und bekannte Milbenarten der Überfamilie Pygmephoroidea aus dem Saalkreis bei Halle (Acarina, Tarsonemida). Ent Mitt Zool Mus Hamburg. 4:499-521.

Sevastianov VD, Chydyrov PR. 1991. New mite species of family Pygmephoridae (Trombidiformes) from the cotton-growing Biocenosis. Zool Zh. 70:134-139. Russian.

Sevastianov VD, Zahida Al Douri ND. 1988. New species of mites of cohort Tarsonemina (Trombidiformes) from wheat plantations. Zool Zh. 67:1080-1083. Russian.

Zhang ZQ, Fan QH, Pesic V, Smit H, Bochkov AV, Khaustov AA, Baker A, Wohltmann A, Wen TH, Amrine JW, et al. 2011. Order trombidiformes Reuter, 1909. In: Zhang ZQ, editor. Animal biodiversity: an outline of higher-level classification and survey of taxonomic richness. 3148. Auckland: Zootaxa; p. 129-138. 